\title{
IMPLEMENTASI ETIKA BISNIS, KONSEP PRODUKSI, EFESIENSI PENGOLAHAN PADA UMKM TERHADAP SISTEM SOSIAL EKONOMI PERSPEKTIF EKONOMI ISLAM
}

\author{
Adinda Thaliya ${ }^{1}$, Muhammad Iqbal Fasa ${ }^{2}$, Suharto ${ }^{3}$ \\ Universitas Islam Negeri Raden Intan Lampung ${ }^{1,2,3}$ \\ adindathaliya107@,gmail.com ${ }^{1}, \underline{\text { miqbalfasa@,radenintan.ac.id }}{ }^{2}$, prof.suharto@,radenintan.ac.id ${ }^{3}$
}

\begin{abstract}
This study is aimed at determining how the concept and implementation of Islamic business ethics, concepts of production, and processing efficiency for small businesses (SMEs) toward the socio-economic system. The purpose of this study is to determine how the concept of Islamic business ethics, concepts of production, and processing efficiency. Then how its implementation for small businesses (SMEs) in which the results of this study might be used as a resume of a model for other small businesses (SMEs) concerning Islamic business ethics, concepts good production, and processing efficiency well for the socio-economy. This research was conducted with a qualitative descriptive research method which using literature studies and resumes the results of previous research. The results showed that small businesses (SMEs), namely industry of coffee powder Cap Jempol Super Kedaton, Bandar Lampung has fulfilled the standards principles of Islamic business ethic and through this research it can also be seen that the MSMEs studied has fulfilled the standards of production concepts in Islam and has execute processing efficiency well.
\end{abstract}

Keywords: Business Ethics, Concept Of Production, Processing Efficiency, Socio-Economic System

\section{PENDAHULUAN}

Pembangunan perekonomian suatu bangsa berasal dari segala elemen-elemen yang terdapat didalamnya, yang mana semua elemen memiliki keterkaitan yang sangat erat. Kesejahteraan masyarakat dapat lihat dari suatu perekonomiannya, maka semakin banyak masyarakat yang dapat menjamin kebutuhan hidupnya dengan memiliki pekerjaan tetap atau memiliki usaha sendiri sehingga dapat merasakan hidup yang layak maka hal ini melambangkan semakin baik kesejahteraan pada masyarakat tersebut. Tak sedikit masyarakat yang membangun bisnis atau usaha nya sendiri yang biasa disebut usaha mikro kecil menengah (UMKM). UMKM memiliki peranan yang sangat penting sehingga dapat menciptakan lapangan pekerjaan dan 
membangkitkan perekonomian masyarakat. Namun dalam suatu bisnis terdapat banyak hal-hal yang harus diperhatikan dalam perjalanan bisnis tersebut.

Bahasan tentang etika bisnis mendapat perhatian yang sangat tinggi dalam ekonomi Islam, Bisnis dalam kehidupan ini merupakan kegiatan yang sangat penting masyarakat dalam menjalani kehidupan mereka. Dunia bisnis berfungsi sebagai suatu kegiatan sosial yang harus mengimplementasikan etika-etika yang berlaku dimasyarakat. Para pengusaha harus berupaya dalam menjauhkan adanya penyalahgunaan hanya untuk keuntungan pribadi tanpa mempedulikan pihak lain, masyarakat, bahkan dapat merugikan bangsa. Penerapan etika bisnis Islam tersebut juga harus mampu dilaksanakan dalam setiap aspek perekonomian termasuk dalam penyelenggaraan produksi, konsumsi maupun distribusi.(Fauzia, 2018)

Prinsip produksi dalam Islam berarti menghasilkan sesuatu yang halal yang mana merupakan akumulasi dari semua proses produksi mulai dari sumber bahan baku sampai dengan jenis produk yang dihasilkan baik berupa barang maupun jasa.(Turmudi, 2017)Maka etika bisnismerupakan komponen penting dalam aktivitas bisnis. Etika bisnis Islam ialah aturan-aturan bisnis yang dikonsep dengan nilai-nilai ajaran Islam. Etika bisnis tidak hanya digunakan guna menjaga berbagai kepentingan dalam bisnis saja, namun lebih dari itu karena pelaksanaannya memberikan jaminan kepada pihak-pihak yang terlibat dalam bisnis untuk memperoleh keberkahan dari bisnisnya.(Zamzam, H Fakhry \& Aravik, 2020)

Dalam kegiatan perekonomian dibutuhkan efesiensi dalam suatu pengolahan atau biasa disebut dengan efesiensi pengolahan. Yang mana merupakan Suatu kegiatan dengan adanya usaha minimum namun dapat mencapai output tertentu atau maksimal, hal mencakup material, pikiran, tenaga, dan waktu. Efesiensi pengolahan tentunya harus dilakukan dengan baik dan tidak merugikan pihak lain.(Wulandari and Widiyanti, 2017)

Basis utama sistem ekonomi syariah sesungguhnya terletak pada aspek kerangka dasarnya yang berlandaskan syariah, tetapi juga pada aspek tujuannya yaitu mewujudkan suatu tatanan ekonomi masyarakat yang makmur dan sejahtera secara berkeadilan, pemerataan, dan keseimbangan berdasarkan system sosial ekonomi. Atas dasar itu, maka pemberdayaaan ekonomi syariah di Indonesia hendaknya dilakukan dengan strategi yang ditujukan bagi perbaikan kehidupan dan ekonomi masyarakat.(Baidowi, 2016)Dengan adanya etika bisnis Islam, konsep produksi dalam Islam, dan efesiensi pengolahan yang baik maka diharapkan mampu menjaga dan memelihara pelaku maupun kegiatan bisnis agar sesuai dengan tuntunan syariat, tidak merugikan orang lain serta mengutamakan keuntungan diakhirat dan bukan hanya keuntungan dunia semata.(Syahrizal, 2018) 
Berdasarkan penelitian terdahulu tentang penerapan etika bisnis Islam yang dilakukan oleh Abdul Hamid dan Muhammad Kamal Zubair dari Institut Agama Islam Negeri (IAIN) Parepare pada tahun 2019, yang mana hasil temuan dalam penelitiannya adalah implementasi etika Islam dalam pemasaran produk Bank Syariah. Dalam penelitiannya menjelaskan bahwa Bank syariah Parepare mampu mengimplementasikan nilai-nilai syariah dalam kegiatan pemasarannya. Penerapan etika bisnis Islam pada tenaga pemasar bank syariah dinilai sangat tepat. Maka dengan adanya bank syariah yang mempunyai kualitas tenaga pemasaran berbasis etika Islam dapat membangun reputasi bank syariah.(Hamid and Zubair, 2019).

Setelah itu, terdapat penelitian terdahulu yang dilakukan oleh Himawan Arif Susanto dan Sri Imanningati pada tahun 2014 yang mana dalam penelitiannya membahas tentang efesiensi poengolahan dengan judul tingkat efisiensi produksi dan pendapatan pada usaha pengolahan ikan asin skala kecil. Pada penelitiannya menjelaskan bahwa hasil analisis data yangtelah diperoleh yaitu bahwa nilai rata-rata efisiensi teknis pengolah ikan asin skalakecil sebesar 0,73397 yang berarti pelaku usaha pengolahan ikan asin di KotaPekalongan belum seluruhnya melakukan kegiatannya secara efisien sehingga masihdimungkinkan untuk menambah beberapa variabel inputnya untuk dapat meningkatkan hasil yang optimal. Variabel Bahan baku, peralatan dan luas usaha berpengaruh signifikan terhadap produksi pengolahan ikan asin di Kota Pekalongan. Usaha Pengolahan ikan asin skala kecil di Kota Pekalongan masih cukup menguntungkan yang ditunjukkan oleh nilai $\mathrm{R} / \mathrm{C}$ rasio sebesar 1,37 yang menunjukkan bahwa besarnya penerimaan pelaku usaha pengolahan ikan skala kecil masih lebih besar dibandingkan dengan biaya-biaya yang harus dikeluarkan dalam menjalan usaha.(Sutanto and Imaningati, 2014).

Kemudian, terdapat pula penelitian terdahulu yang dilakukan olehMuh,Yusuf dan Andi Agustang yang membahasa tentang sosial ekonomi pada tahun 2020. Dengan hasil penelitiannya yang berjudul dinamika perubahan sosial ekonomi pada masyarakat Kindang Kabupaten Bulukumba, pada penelitiannya menjelaskan bahwa perubahan sosial ekonomi pada masyarakat Kindang Kabupaten Bulukumba dilandasi oleh berbagai faktor yakni faktor eksternal seperti pengaruh budaya luar dan perkembangan teknologi dan faktor internal seperti letak geografis, Dampak dari meningkatnya perekonomian masyarakat Kindang sangat mempengaruhi tingkat Pendidikan, politik, dan budaya. Ditengah- tengah berkembangnya perekonomian masyarakat Kindang, yang mana hal ini sangalah mempengaruhi perubahan sosial ekonomi pada masyarakat Kindang, Kabupaten Bulukumba.(Yusuf and Agustang, 2020) 
Thaliya, Fasa, Suharto. Implementasi Etika Bisnis, Konsep Produksi, dan Efesiensi

\section{METODOLOGI}

Pada penelitian ini, metode penelitian yang digunakan yakni metode penelitian deskriptif kualitatif. Jenis metode penelitian deskriptif kualitatif memiliki arti yaitu sebuah metode penelitian yang mana memanfaatkan data kualitatif dengan menjabarkan data tersebut secara deskriptif. Jenis penelitian deskriptif kualitatif kerap digunakan untuk menganalisis kejadian, fenomena, atau keadaan secara sosial.(Syahrul, 2017). Hal yang diamati dari penelitian ini adalah tentang etika bisnis, konsep produksi, dan efesiensi pengolahan dalam Islam yang dijalankan oleh UMKM industri kopi bubuk Cap Jempol Kedaton, Bandar Lampung terhadap system sosial ekonomi.

Dalam penelitian ini populasi yang dimaksud adalah seluruh elemen yang terlibat dalam produksi kopi bubuk pada UMKM industri kopi bubuk Cap Jempol Kedaton, Bandar Lampung dan seluruh konsumen kopi bubuk Cap Jempol. Sampel merupakan suatu sub kelompok dari populasi yang dipilih untuk digunakan dalam penelitian. Dalam Penelitian ini, melalui teknik random sampling, yang terpilih ialah sebanyak 6 orang yang terdiri dari 1 orang pemilik usaha industry kopi bubuk Cap jempol, 2 karyawan, dan 3 konsumen. Lokasi Penelitian ini dilakukan pada UMKM industri kopi bubuk Cap Jempol yang beralamat pada Jalan Untung Suropati Gg. Transmigrasi,Kedaton, Bandar Lampung. Penilitian ini melibatkan pihak yang berkepentingan terkait etika bisnis, konsep produksi, dan efesiensi pengolahan yang dijalankan. Dengan ini peneliti beberapa variabel yaitu etika bisnis, konsep produksi, efesiensi pengolahan, dan system sosial ekonomi.

Metode pengumpulan data yang digunakan adalah Wawancara, wawancara adalah teknik pengumpulan data dalam metode survei yang menggunakan pertanyaan secara lisan kepada subjek penelitian. Hal ini dilakukan untuk memperoleh data primer. Wawancara dilakukan guna mengetahui pengalaman atau pendapat informan mengenai sesuatu secara mendalam dan lengkap. Wawancara yang digunakan adalah wawancara secara satu per satu, yaitu proses pengumpulan data dimana peneliti mengajukan pertanyaan dan merekam jawaban dari partisipan satu per satu. Dalam penelitian ini metode pengelohan data yang digunakan adalah metode analisis data. Analisis data merupakan suatu cara untuk menguraikan dan memecahkan suatu keseluruhan menjadi bagian-bagian atau komponen- komponen yang lebih kecil. Metode analisis yang digunakan adalah dengan menggunakan pendekatan deskriptif yaitu apa yang dinyatakan oleh responden secara tertulis maupun lisan dan perilaku yang nyata, kemudian diamati dan diteliti sebagai suatu data yang utuh.(Irawan, 2017) Dalam hal ini data yang telah didapat akan dianalisa sesuai dengan kajian penelitian yaitu implementasi etika bisnis, konsep produksi, dan 
efesiensi pengolahan dalam Islam yang dijalankan pada UMKM industri kopi bubuk Cap Jempol Super Kedaton, Bandar Lampung terhadap system sosial ekonomi.

\section{HASIL DAN PEMBAHASAN}

\section{Penerapan Etika Bisnis Islam}

Etika adalah suatu filsafat moral yang mana membicarakan tentang sikap dan perbuatan yang baik dan yang buruk. Etika berasal dari bahasa Yunani yaitu "ethos" yang memiliki arti adat, kebiasaan, dan cara bertindak. Sedangkan, Bisnis diartikan sebagai suatu kegiatan yang dilakukan oleh manusia guna memperoleh pendapatan atau penghasilan dalam upaya memenuhi kebutuhan dan keinginan hidup dengan mengelola sumber daya ekonomi yang dilakukan secara efektif dan efisien.(Juliyani, 2016)

Etika ialah kaidah atau prinsip-prinsip yang mengatur hidup manusia, yang mana merupakan bagian dari filsafat yang didalamnya membahas tentang norma atau moralitas secara rasional dan kritis.(Putritama, 2018) Etika menurut Islam termasuk nilai dasar akhlak yang menjadi satu kesatuan dengan nilai dasar Islam lainnya, yakni aqidah dan syariah.(Samad, 2018) Dengan berpandangan oleh etika, maka keputusan moral seseorang menjadi memiliki alasan karena keputusan yang diambil tersebut terlepas dari pengaruh sewenang-wenang melainkan dengan memperhatikan norma atau moral secara rasional.(Sudarmanto, 2020)

Dengan demikian dapat diketahui bahwa, Etika bisnis merupakan suatu tata cara, norma, atau kaidah yang baik dalam menjalankan bisnis. Dalam Islam suatu bisnis pada hakikatnya merupakan usaha manusia yang bertujuan guna mencari keridhaan dari Allah SWT. Suatu bisnis tidak hanya memiliki tujuan dalam jangka pendek, secara individual dan semata-mata demi keuntungan yang berdasarkan kalkulasi matematika, tetapi bisnis bertujuan jangka pendek sekaligus jangka panjang, yaitu dengan adanya tanggung jawab pribadi, Allah SWT, sosial masyarakat, serta negara. Sedangkan norma sendiri memiliki arti yang mana sebagai petunjuk atau perintah, dan setidak-tidaknya menjadi sebuah harapan.(Fajrillah, 2020)

Fungsi khusus yang terdapat dalam etika bisnis Islam yaitu etika bisnis berupaya mencari cara untuk menyelaraskan dan menyerasikan berbagai kepentingan dalam dunia bisnis, etika bisnis juga mempunyai peran untuk senantiasa melakukan perubahan kesadaran bagi masyarakat tentang bisnis, terutama bisnis Islami. Dan caranya biasanya dengan memberikan suatu pemahaman serta cara pandang baru tentang bisnis dengan menggunakan landasan nilai-nilai moralitas dan spiritualitas, yang kemudian terangkum dalam suatu bentuk bernama etika bisnis, kemudian etika bisnis Islami juga bisa berperan memberikan satu solusi terhadap berbagai persoalan bisnis modern ini yang kian jauh dari nilai-nilai etika. Dalam arti bahwa bisnis yang 
Thaliya, Fasa, Suharto. Implementasi Etika Bisnis, Konsep Produksi, dan Efesiensi

beretika harus benar-benar merujuk pada sumber utamanya yaitu Al-Quran dan Sunnah.(Hidayah, 2015)

Dalam etika bisnis Islam terdapat beberpa prinsip-prinsip, sebagai berikut :

1) Tauhid merupakan perpaduan seluruh aspek kehidupan baik ekonomi, sosial, politik budaya menjadi keseluruhan yang homogen, konsisten dan teratur. Dari konsepsi ini, Islam menawarkan adanya keterpaduan antara agama, ekonomi, dan sosial demi membentuk suatu kesatuan. Oleh karena itu, maka pengusaha muslim dalam melakukan suatu aktivitas bisnis haruslah memperhatikan tiga hal, yaitu tidak melakukan diskriminasi terhadap pekerja, pembeli, dan mitra kerja, Allah SW'T yang sangat ditakuti dan dicintai, serta tidak melakukan penimbunan kekayaan atau serakah, karena hakikatnya kekayaan merupakan amanah dari Allah SWT.(Bakhri and Purnama, 2018)

Dari hasil analisis, UMKM industri kopi bubuk Cap Jempol Super Kedaton, Bandar Lampung dianggap telah memenuhi prinsip tauhid ini. Berdasarkan hasil survey UMKM tersebut, pemilik sangat mengutamakan perihal ibadah dan tidak pernah melakukan diskriminasi terhadap pekerja maupun pembeli serta pemilik sangat mengetahui dengan jelas betapa buruknya penimbunan kekayaan atau serakah.

2) Keseimbangan (Keadilan) adalah ajaran Islam berorientasi pada terciptanya suatu karakter yang dimiliki manusia yaitu sikap dan prilaku yang seimbang dan adil dalam hubungan antara manusia dengan individu, dengan manusia lain (masyarakat) dan dengan lingkungan sekitar. Keseimbangan dalam Islam seperti yang ditekankan oleh Allah SWT dengan menyebut umat Islam sebagai ummatan wasatha, yang mana ummatan wasathan ialah umat yang memiliki kebersamaan, kedinamisan dalam gerak dan arah, serta tujuannya dengan adanya aturan-aturan kolektif yang berfungsi sebagai penengah atau pembenar. Dengan ini, maka keseimbangan, kebersamaan, kemodernan merupakan suatu prinsip etis mendasar yang harus diterapkan dalam aktivitas bisnis.(Bakhri and Purnama, 2018)

Berdasarkan hasil dari wawancara, pelayanan pada seluruh pelanggan dilakukan secara adil dan tidak ada pembeda begitu pula dengan semua karyawan. Pengolahan pun dilakukan secara benar dan halal agar tidak merugikan pihak konsumen. Sehingga hal tersebut dapat membantu peningkatan kesejahteraan masyarakat. 
3) Kehendak Bebas, manusia ialah sebagai khalifah di muka bumi ini, namun tetaplah memiliki batas-batas tertentu dalam kehendak bebas guna mengarahkan kehidupan kepada tujuan yang akan dicapai. Manusia dianugerahi oleh Allah SWT kehendak bebas (free will) sebagai penuntun kehidupan sebagai khalifah. Berdasarkan kehendak bebas ini, dalam bisnis manusia mempunyai kebebasan untuk membuat suatu perjanjian atau tidak, melaksanakan bentuk aktivitas bisnis tertentu, berkreasi mengembangkan potensi bisnis yang ada.(Bakhri and Purnama, 2018) Kebebasan disini ialah kebebasan yang bertanggung jawab dan tidak menerobos kepentingan orang lain.(Medias, 2018)

Berdasarkan hasil wawancara dengan Bapak Muhammad Yazid selaku pemilik dari industry kopi bubuk Cap Jempol Sumper, karyawan yang membantu pada UMKM industri kopi bubuk Cap Jempol Super Kedaton, Bandar Lampung tidak pernah dikekang ataupun adanya hal-hal yang memberatkan pada saat bekerja. Dengan begitu keberadaan UMKM industri kopi bubuk Cap Jempol Super Kedaton, Bandar Lampung dirasa dapat membantu dalam hal peningkatan pendapatan masyarakat sekitar kecamatan Kedaton, Bandar Lampung.

4) Pertanggungjawaban, dalam Islam tanggung jawab pada dasarnya bersifat sukarela dan tanpa paksaan. Dalam perspektif etika bisnis tanggung jawab kepada Tuhan ialah karena manusia menyadari bahwa dalam melakukan suatu aktivitas bisnis segala objek yang diperdagangkan pada hakikatnya hal tersebut adalah anugerahNya. Sedangkan, tanggung jawab kepada manusia ialah karena manusia adalah mitra yang harus dihormati hak dan kewajibannya. Islam tidak mentolelir pelanggaran atas hak dan kewajiban itu sehingga di sinilah arti penting pertanggungjawaban itu harus dipikul oleh manusia.(Bakhri and Purnama, 2018)

Dalam hal ini penulis telah mendapat penjelasan dari narasumber bahwa industri kopi bubuk Cap Jempol Super Kedaton, Bandar Lampung ini disajikan sesuai dengan standar penyediaan makanan dengan baik yang mana tidak menggunakan bahan-bahan berbahaya sehingga tetap aman dikonsumsi oleh pelanggan dan sangat disiplin dalam mengutamakan kesehatan. Maka dapat diketahui bahwa pada umkm tersebut menerapkan prinsip pertanggungjawaban terutama pada produk yang akan dijual. 
Dari hasil penelitian ini, terlihat jelas bahwa UMKM industri kopi bubuk Cap Jempol Super Kedaton, Bandar Lampung telah menerapkan etika bisnis yang baik sesuai dengan pedoman etika bisnis Islam.

Maka, dengan adanya penerapan etika mengarahkan manusia menuju aktualisasi kapasitas terbaiknya. Penerapan etika dan kejujuran dalam bisnis akan meningkatkan nilai entitas bisnis itu sendiri. Dengan tingkat persaingan yang semakin tinggi ditambah dengan konsumen yang semakin kritis, maka kalua kepusan konsumen tetap dijaga akan menyebabkan suatu bisnis dapat berkelanjutan (sustainable) dan dapat dipercaya dalam jangka panjang. Suatu bisnis yang menerapkan etika akan meningkatkan motivasi para pekerja, karena bekerja selain dituntut menghasilkan yang terbaik, juga diperoleh dengan cara yang baik pula. Penerapan etika bisnis juga melindungi prinsip kebebasan berusaha dan meningkatkan keunggulan bersaing, selain itu juga mencegah terkena sanksi-sanksi pemerintah karena melanggar etika yang dapat digolongkan sebagai perbuatan melawan hukum. Tanpa etika bisnis maka, suatu bisnis yang dijalankan akan mementingkan kepentingan bisnisnya sendiri dengan menggunakan berbagai cara dan mengorbankan apa saja demi mencapai tujuan, yang mana hal ini sangatlah mempunyai dampak yang buruk bagi suatu bisnis yang dijalankan.(Nawatmi, 2010)

\section{Penerapan konsep produksi dalam islam}

Produksi ialah suatu aktivitas dalam mengelolah bahan mentah menjadi bahan bahan setengah jadi atau mengelolah bahan setengah jadi menjadi bahan jadi yang memiliki tujuan guna mengoptimalkan faktor produksi sehingga output produk dapat mempermudah terpenuhinya atau tercapainya kebutuhan manusia.(Utami, 2020). Manfaat adanya suatu produksi yaitu menghasilkan bahan-bahan kebutuhan manusia baik berasal dari tumbuhan maupun hewan yang disertai dengan adanya usaha untuk memperbaharui, mengembangan, serta mempertimbangkan faktor ekonomi.(Maisyaroh, 2019)

Tujuan Produksi dalam Islam menurut Khalifah Umar bin Khatab, tujuan produksi yaitu merealisasikan keuntungan seoptimal mungkin, merealisasikan kecukupan individu dan keluarga, tidak mengandalkan orang lain, melindungi harta dan mengembangkannya, mengeksplorasi sumber-sumber ekonomi dan mempersiapkannya untuk dimanfaatkan, pembebasan dari belenggu ketergantungan ekonomi, dan taqarrub atau melaksanaan ketaatankepada Allah SWT (Turmudi, 2017). Konsep produksi dalam Islam memiliki beberapa prinsip sebagai berikut.

1) Akidah, dibagi menjadi 2 yaitu: 
a. Illahiyah, dimana segala sesuatu harus berporos kepada Allah SWT. Suatu kegiatan produksi merupakan manifestasi ketundukan pada Tuhan sehingga dapat dikatakan sebagai sebuah ibadah.(Turmudi, 2017)

Dari konsep produksi yang telah dijelakan diatas, dapat dikatakan telah memenuhi hal tersebut, dapat dilihat dalam proses produksi yang dilakukan pada industri kopi tersebut yang mana menggunakan biji kopi yang berkualitas dan pada proses pengolahan pun menjauhkan dari hal-hal yang haram dengan tujuan mendapatkan ridho Allah SWT.

b. Rabbaniyah, yaitu peningkatan kesejahteraan individu dan masyarakat menjadi tujuan utama dari kegiatan produksi yang berbasis kemanusiaan. (Turmudi, 2017) Pada prinsip rabbaniyah penulis dapat menyimpulkan bahwa UMKM industri kopi bubuk Cap Jempol Super Kedaton, Bandar Lampung telah melakukan prinsip tersebut karena dalam proses produksi yang tidak membuang limbah sembarangan dan terkadang penjual juga memberikan sebagian dari produksinya yang dibuat lebih untuk kerabat dan tetangganya.

2) Syariah (Hukum Islam), yang mana hakl ini erkait dengan halal dan haram, serta kerugian bagi masyarakat sekitar, kecurangan, dan sebagainya.(Turmudi, 2017) Dari konsep produksi tersebut, maka penulis dapat menyimpulkan bahwa UMKM industri kopi bubuk Cap Jempol Super Kedaton, Bandar Lampung telah melaksakan hal yang benar dan sesuai dengan syariah atau hukum islam. Dalam produksi barang yang dijual, sebelum memulai proses produksi telah dipastikan terlebih dahulu kehalalan dari bahan-bahan yang digunakan yaitu dari biji kopi dan mentega yang digunakan. Dalam produksi ini juga telah memastikan harga berdasar harga pasarannya. sehingga tidak menjatuhkan harga pasar atau pesaingpesaingnya. Dalam hal kecurangan, penjual sangat teliti pada bahan-bahan yang digunakan sehingga dapat mencegah adanya kecurangan dalam segi pengolahan maupun penjualan. Dapat dilihat UMKM industri kopi bubuk Cap Jempol Super Kedaton, Bandar Lampung telah mendapatkan izin pada Dep.Kes.RI.No : 131/108.01/95 dan izin industry No. 478/187/XII/95.

3) Akhlak, yang mana hal ini terkait dengan inovasi dan efesiensi sumber daya alam yang dipergunakan.(Turmudi, 2017)

Dari konsep produksi tersebut, dapat diambil kesimpulan bahwa UMKM industri kopi bubuk Cap Jempol Super Kedaton, Bandar Lampung tidak sembarangan dalam pengolahan biji kopi yang digunakan, berdasarkan pernyataan narasumber 
bahwa dalam penggunaan sumber daya alam yang digunakan dilakukan secara bertahap dan tidak berlebihan sesuai dengan kebutuhan konsumen dan kemampuan dari alat produksi yang ada.

Dari hasil penelitian ini, dapat diketahui bahwa UMKM industri kopi bubuk Cap Jempol Kedaton, Bandar Lampung telah menerapkan konsep produksi dalam Islam dengan baik.

\section{Penerapan Efesiensi Pengolahan}

Efisiensi dalam pengolahan yaitu adanya suatu perbandingan antara output dan input berhubungan dengan tercapainya output maksimum dengan sejumlah input, yang berarti jika ratio output besar, maka efisiensi dikatakan semakin tinggi. Efisiensi ialah suatu tindakan yang bertujuan memaksimalkan hasil dengan menggunakan modal seperti tenaga kerja, material dan alat secara minimal. Selain itu efisiensi sangat berhubungan dengan pemasukan dan pengeluaran. Usaha dalam peningkatan efisiensi pada umumnya dihubungkan dengan adanya biaya yang lebih kecil guna memperoleh suatu hasil atau biaya yang lebih banyak. Hal ini berarti menekan pemborosan hingga sekecil mungkin.(Sutanto and Imaningati, 2014)

Suatu kegiatan dapat diketahui efisien atau tidak jika usaha yang telah dilakukan memberikan output yang maksimum, yang dapat dilihat dari jumlah maupun kualitasnya. Kemudian, suatu kegiatan juga dapat disebut efisien bila dilakukan dengan usaha yang minimum namun dapat mencapai output tertentu. Usaha tersebut meliputi material, pikiran, tenaga jasmani, ruang, dan waktu.(Wulandari and Widiyanti, 2017)

Pada UMKM industri kopi bubuk Cap Jempol Super Kedaton, Bandar Lampung mengunakan tenaga kerja yang relatif sedikit karena dalam proses pengolahan dibantu oleh anggota keluarga yang ada, kemudian dari ketersediaan bahan disesuaikan dengan kemampuan dari alat yang telah tersedia. Pada pengolahan biji kopi, UMKM industri kopi bubuk Cap Jempol Super Kedaton, Bandar Lampung hanya memiliki 2 alat pengolahannya. Namun, walaupun adanya keterbatasan dengan alat UMKM industri kopi bubuk Cap Jempol Super Kedaton, Bandar Lampung dapat menghasilkan berkilo-kilo kopi bubuk perharinya yang kemudian sangatlah laku dipasaran.

\section{Sistem Sosial Ekonomi}

Sosial ekonomi yaitu suatau posisi, kedudukan, jabatan, kepemilikan yang dimiliki seorang individu ataupun kelompok yang berkaitan dengan tingkat pendidikan, tingkat pendapatan, kepemilikan asset rumah tangga, dan pemenuhan kebutuhan keluarga serta pekerjaan yang 
dimiliki yang akan sangat mempengaruhi status sosial seseorang, kelompok ataupun keluarga di lingkungan masayarakatnya.(Yakub Pirdaus, 2019)

Dalam system sosial ekonomi, terdapat peraturan-peraturan yang bertujuan untuk menghindari ketimpangan dalam kemakmuran tersebut. Berikut adalah perlindungan dalam hukum ekonomi terutama pada kegiatan UMKM salah satunya yaitu Prinsip ekonomi. Dalam UUD 1945, prinsip ini seperti yang dirumuskan oleh the founding father atau pembentukUUD 1945 yang telah memikirkan dengan matang bangunan ekonomi bagi bangsa Indonesia, melalui prinsip ekonomi guna mencapai tujuan nasional yaitu masyarakat adil dan makmur. Artinya kemakmuran rakyat dapat diperoleh melalui kegiatan ekonomi yang sehat dan jauh dari praktik-praktik persaingan usaha yang tidak sehat. Apabila diperhatikan dengan seksama, ada 7 asas prinsip ekonomi yang dimuat dalam Pasal 33 UUD 1945, yaitu prinsip keseimbangan, keserasian dan keselarasan, persamaan, usaha bersama, kekeluargaan, musyawarah untuk mufakat (demokrasi ekonomi), manfaat, perlindungan dan pembinaan pihak yang lemah.(Arliman, 2017)

Kemudian, terdapat pula peraturan yang ditujukan agar terjadinya kemakmuran masyarakat sebagai konsumen yang mana telah diatur pada hak-hak konsumen dalam Pasal 4 UUPK yaitu adanya hak atas kenyamanan, keamanan, dan keselamatan dalam mengkonsumsi suatu barang atau jasa, hak untuk memilih serta mendapatkan barang atau jasa sesuai dengan nilai tukar dan kondisi serta jaminan yang telah dijanjikan, mendapatkan hak atas informasi yang benar, jelas, dan jujur, adanya hak untuk didengar pendapat dan keluhannya, hak untuk diperlakukan atau dilayani secara benar dan jujur serta tidak diskriminatif, dan lain sebagainya.(Setiantoro et al., 2018)

Menurut Mannan dalam (Oktabriani, 2018) berpendapat bahwa kesejahteraan berkaitan dengan proses produksi. Prinsip fundamental yang harus selalu diperhatikan dalam proses produksi adalah kesejahteraan ekonomi, konsep kesejahteraan ekonomi dalam Islam terdiri dari bertambahnya pendapatan yang diakibatkan oleh meningkatnya produksi dari barang yang berfaedah melalui pemanfaatan sumberdaya yang ada secara maksimum, baik manusia maupun benda, selanjutnya diiringi dengan perbaikan sistem produksi, ditandai dengan terpenuhinya kebutuhan maksimal dengan usaha minimal namun dalam hal konsumsi tetap berpedoman pada nilai-nilai keislaman. Oleh karena itu, dalam pandangan Islam, meningkatnya produksi barang belum tentu menjamin kesejahteraan secara ekonomi, karena disamping peningkatan produksi juga harus memperhitungkan akibat yang ditimbulkan dari barang-barang yang diproduksi.

Maka, dapat diketahui bahwa sistem sosial ekonomi ialah suatu system yang bertujuan untuk kepentingan kemakmuran atau kesejahteraan masyarakat secara keseluruhan atau tidak 
timpang. Yang mana telah diatur oleh pemerintah. Sistem sosial ekonomi dalam Islam sangat menekankan keseimbangan yang adil antara individu dan masyarakat.

Pengertian kesejahteraan menurut Undang-undang No 11 Tahun 2009, tentang Kesejahteraan Masyarakat, kesejahteraan masyarakat adalah kondisi terpenuhinya kebutuhan material, spiritual, dan sosial warga negara agar dapat hidup layak dan mampu mengembangkan diri, sehingga dapat melaksanakan fungsi sosialnya. Dari Undang-Undang di atas dapat kita cermati bahwa ukuran tingkat kesejahteraan dapat dinilai dari kemampuan seorang individu atau kelompok dalam usaha nya memenuhi kebutuhan material dan spiritual nya. Kebutuhan material dapat kita hubungkan dengan pendapatan yang nanti akan mewujudkan kebutuhan akan pangan, sandang, papan dan kesehatan. Kemudian kebutuhan spiritual kita hubungkan dengan pendidikan, kemudian keamanan dan ketentaraman hidup.(Hapsari and Kinseng, 2018)

Sedangkan, Kesejahteraan menurut Islam terbagi menjadi dua, yaitu pertama ialah kesejahteraan Holistic yang seimbang, yaitu mencakup dimensi material maupun spiritual serta mencakup individu maupun social. Manusia akan merasa bahagia jika terdapat keseimbangan antara dirinya dan lingkungan sosialnya. yang kedua yaitu kesejahteraan di dunia maupun di akhirat, sebab manusia tidak hanya hidup di dunia saja tetapi juga di akherat kelak. Jika kondisi ideal ini bisa dicapai maka kesejahteraan di akherat tentu lebih diutamakan, karena kehidupan akhirat yang abadi dan bernilai daripada kehidupan dunia.(Indrarini, 2017)

Dengan adanya penerapan etika bisnis, konsep produksi, dan efesiensi pengolahan dengan benar tentu sangat membantu terciptanya keselarasan antara kegiatan ekonomi maupun sosial yang kemudian akan memberikan dampak yang baik pula bagi seluruh elemen masyarakat. Kemudian, peranan dari etika bisnis Islam, konsep produksi, dan efesiensi pengolahan yang dijalankan dengan baik oleh UMKM industri kopi bubuk Cap Jempol Super Kedaton, Bandar Lampung maka hal ini dapat memaksimalkan berlakunya system sosial ekonomi yang memiliki tujuan untuk kepentingan kemakmuran atau kesejahteraan masyarakat secara keseluruhan dan tidak timpang serta menekankan adanya keseimbangan yang adil antara pemilik UMKM dan masyarakat.

\section{Keterkaitan Sistem Sosial Ekonomi dengan Usaha Mikro Kecil}

Terdapat keterkaitan yang sangat signifikan dari adanya usaha mikro kecil dengan peningkatan system sosial ekonomi pada masyarakat. Berikut adalah data pada tahun 2017 yang menjelaskan penyerapan tenaga kerja dari adanya usaha mikro kecil. 


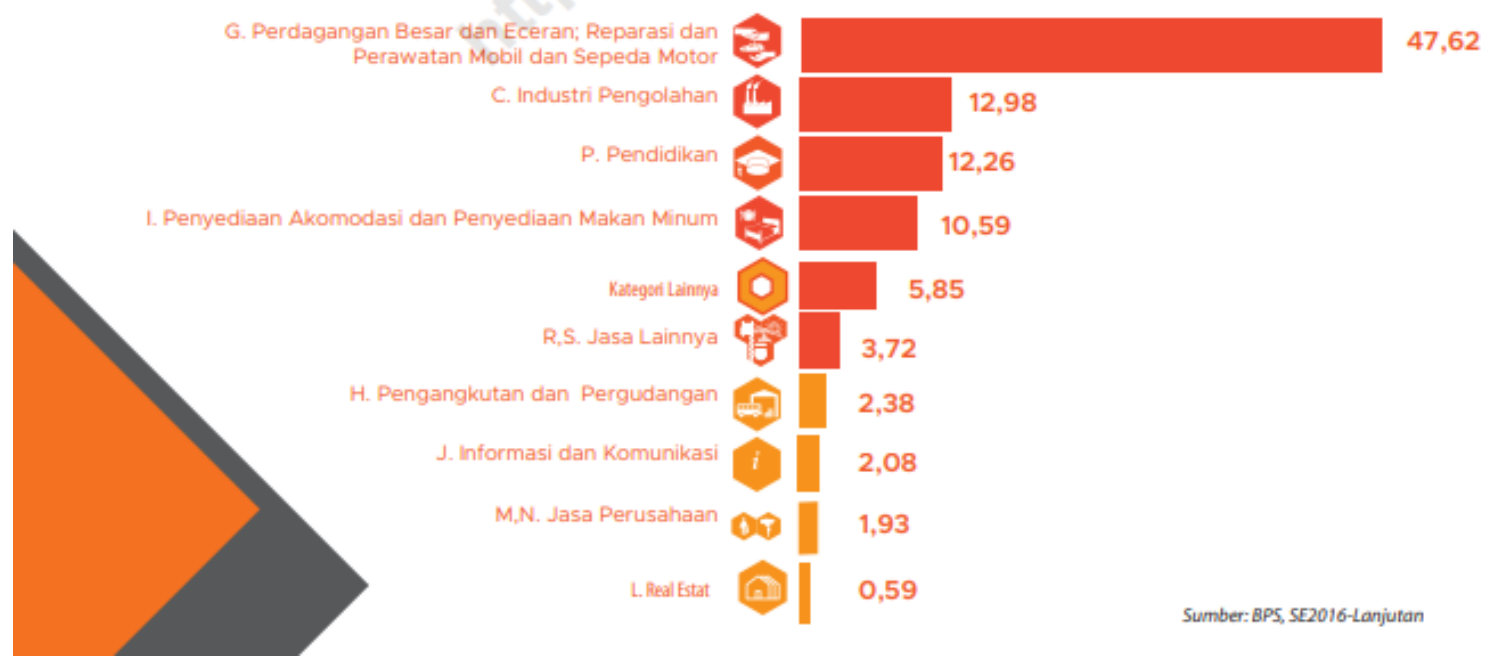

Gambar 1. Persentase Penyerapan Tenaga Kerja Usaha Mikro Kecil Menurut Kategori Pada 2017

Sumber : lampung.bps.go.id

Kemudian terdapat pula data pada tahun 2020 yang menjelaskan persentase penduduk yang bekerja di kegiatan formal dan kegiatan informal.

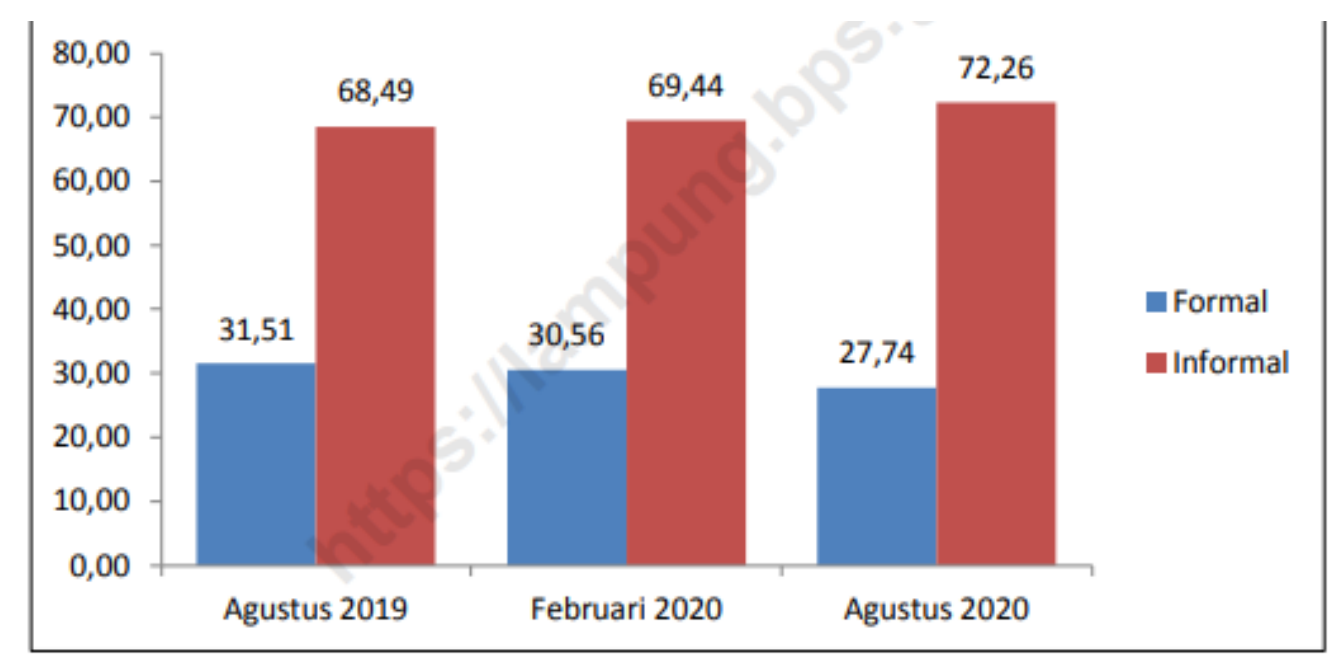

Gambar 2. Persentase Penduduk Bekerja Di Kegiatan Formal Informal, Agustus 2019, Februari 2020, dan Agustus 2020

Sumber : lampung.bps.go.id

Sektor informal dapat tumbuh di manapun karena kehadirannya tidak memerlukan modal yang banyak, pendidikan tinggi, urus izin usaha yang panjang dan teknologi canggih. Faktorfaktor seperti ini dapat mempermudah masyarakat untuk mengembangkan usaha di sektor ini. 
Thaliya, Fasa, Suharto. Implementasi Etika Bisnis, Konsep Produksi, dan Efesiensi

Berdasarkan data tersebut, 72,26 persen tenaga kerja di Lampung adalah tenaga kerja informal. Persentase pekerja informal mengalami peningkatan sebanyak 3,77 persen poin dibandingkan dengan kondisi setahun yang lalu (Agustus 2019). Dengan kata lain, ada penurunan sebesar 3,77 persen poin pada pekerja formal, yaitu menurunnya pekerja yang berstatus buruh atau karyawan.(BPS Lampung, 2020)

Maka adanya usaha mikro kecil memiliki peranan yang sangat penting dalam menggerakkan roda perekonomian Lampung Pengelolaan usaha ini dilakukan secara sederhana sehingga lebih banyak menjadi pilihan sebagai wadah usaha yang menghasilkan nilai ekonomi. Usaha ini menjadi pilihan utama karena memerlukan modal yang relatif kecil. Oleh sebab itu aktivitas usaha mikro kecil merupakan kegiatan ekonomi yang tidak dapat dipisahkan dalam kehidupan masyarakat dalam mencukupi kebutuhan hidup. Dengan kata lain, usaha mikro kecil berperan sebagai basic pembangunan ekonomi kerakyatan sehingga dengan adanya usaha mikro kecil maka akan meningkatkan sistem sosial ekonomi.(BPS Lampung, 2016)

Namun, dalam penerapan usaha mikro kecil diperlukannya keseimbangan antara seluruh elemen masyarakat yang bertujuan untuk kepentingan kesejahteraan masyarakat secara keseluruhan dan tidak timpang. Untuk itu maka, adanya perhatian khusus pada etika bisnis Islam yang baik, konsep produksi dalam Islam yang tidak merugikan pihak lain, dan penerapan efesiensi pengolahan yang benar dapat membantu usaha mikro kecil dalam keberlangsungan bisnis yang dijalankan secara berkelanjutan dan dapat terus mendorong sistem sosial ekonomi yang sehat.

\section{SIMPULAN}

Melalui penelitian ini dapat diketahui bahwa UMKM yang diteliti, yaitu UMKM industri kopi bubuk Cap Jempol Super Kedaton, Bandar Lampung telah memenuhi standard prinsipprinsip etika bisnis Islam dan melalui penelitian ini pula dapat diketahui bahwa UMKM yang diteliti telah memenuhi standard konsep-konsep produksi dalam Islam dan telah melakukan efesiensi pengolahan dengan baik. Melihat kesimpulan yang telah diuraikan diatas, maka terdapat saran yang bagi pihak UMKM tersebut yaitu diharapkan etika bisnis, konsep produksi, dan efesiensi pengolahan yang telah dijalankan dapat terus dilanjutkan dan dipertahankan guna tercapainya tujuan usaha dan terwujudnya system sosial ekonomi yang baik guna tercapainya kesejahteraan ekonomi pada seluruh elemen masyarakat.

Untuk penelitian selanjutnya, hendaknya lebih mendalam lagi dalam membahas etika bisnis, konsep produksi, dan efesiensi produk dalam suatu bisnis terhadap sistem sosial ekonomi agar dapat melihat sejauh mana peningkatan sosial ekonomi dengan adanya penerapan bisnis 
yang benar dari suatu kegiatan bisnis baik dalam perspektif umum maupun perspektif ekonomi Islam.

\section{REFERENSI}

Arliman, L. (2017) 'Perlindungan Hukum UMKM Dari Eksploitasi Ekonomi Dalam Rangka Peningkatan Kesejahteraan Masyarakat', Jurnal Rechts Vinding: Media Pembinaan Hukum Nasional, 6(3), pp. 387-402.

Baidowi, A. (2016) 'Etika Bisnis Perspektif Islam’, Jurnal Hukum Islam, 9(2), pp. 1-12.

Bakhri, S. and Purnama, L. (2018) 'Tinjauan Etika Bisnis Islam Dalam Strategi Pemasaran Home Industri Tahu Sari Rasa', Al-Mustashfa: Jumal Penelitian Hukum Ekonomi Syariah, 3(2), pp. 284-299.

BPS Lampung (2016) Potensi Usaha Mikro Kecil Provinsi Lampung Sensus Ekonomi 2016. Bandar Lampung: BPS Provinsi Lampung.

BPS Lampung (2020) Indikator Kesejabteraan Rakyat Provinsi Lampung 2020. Bandar Lampung: BPS Provinsi Lampung.

Fajrillah (2020) Smart Entrepreneurship. Yayasan Kita Menulis.

Fauzia, I. Y. (2018) Etika Bisnis dalam Islam. Jakarta: Prenada Media.

Hamid, A. and Zubair, M. K. (2019) 'Implementasi Etika Islam Dalam Pemasaran Produk Bank Syariah', BALANCA: Jurnal Ekonomi dan Bisnis Islam, 1(1), pp. 16-34.

Hapsari, A. and Kinseng, R. A. (2018) 'Hubungan Partisipasi Dalam Program Pemberdayaan Umkm Dengan Tingkat Kesejahteraan Peserta', Jumal Sains Komunikasi dan Pengembangan Masyarakat [JSKPM], 2(1), pp. 1-12.

Hidayah, N. S. (2015) 'Persaingan bisnis pedagang pasar Ganefo Mranggen Demak dalam tinjauan etika bisnis Islam'. UIN Walisongo.

Indrarini, R. (2017) 'Pembiayaan Bpr Syariah Dalam Peningkatan Kesejahteraan Umkm: Bedasarkan Maqashid Sharia', JEBIS (Jurnal Ekonomi dan Bisnis Islam), 3(1), pp. 49-60.

Irawan, S. (2017) 'Strategi Program Kemitraan PTPN VII Unit Usaha Kedaton Dalam Pemberdayaan Ekonomi UKM Masyarakat Di Desa Rejosari Natar Lampung Selatan'. IAIN Raden Intan Lampung.

Juliyani, E. (2016) 'Etika Bisnis dalam Perspektif Islam', Jurnal Ummul Qura, 7(1), pp. 63-74.

Maisyaroh, A. (2019) Buku Ajar Agronursing. Lumajang: KHD Production.

Medias, F. (2018) Ekonomi Mikro Islam: Islamic Microeconomics. Magelang: Unimma Press.

Nawatmi, S. (2010) 'Etika bisnis dalam perspektif Islam', Fokus Ekonomi, 9(1), p. 24402.

Oktabriani, E. N. (2018) 'Dampak Eksternalitas Industri Pengolahan Karet Terhadap Kondisi 
Thaliya, Fasa, Suharto. Implementasi Etika Bisnis, Konsep Produksi, dan Efesiensi

Sosial Ekonomi Masyarakat Dalam Perspektif Ekonomi Islam (Studi Kasus Industri Pengolahan Karet Pt Perkebunan Nusantara Vii Unit Way Berulu Desa Kebagusan Dusun Way Berulu Kecamatan Gedong Ta'. UIN Raden Intan Lampung.

Putritama, A. (2018) 'Penerapan Etika Bisnis Islam dalam Industri Perbankan Syariah', Nominal: Barometer Riset Akuntansi dan Manajemen, 7(1), pp. 1-20.

Samad, M. (2018) Etika Bisnis Syariah: Berbisnis Sesuai Dengan Moral Islam. Yogyakarta: Sunrise Book Store.

Setiantoro, A. et al. (2018) 'Urgensi Perlindungan Hukum Konsumen Dan Penyelesaian Sengketa

E-Commerce Di Era Masyarakat Ekonomi Asean', Jurnal Rechts Vinding: Media Pembinaan Hukum Nasional, 7(1), pp. 1-17.

Sudarmanto, E. (2020) Etika Bisnis. Yayasan Kita Menulis.

Sutanto, H. A. and Imaningati, S. (2014) 'Tingkat efisiensi produksi dan pendapatan pada usaha pengolahan ikan asin skala kecil', JEJAK: Jumal Ekonomi dan Kebijakan, 7(1), pp. 73-84.

Syahrizal, A. (2018) 'Etika Bisnis dalam Perspektif Islam', Aktualita: Jurnal Penelitian Sosial Keagamaan, 8(2), pp. 101-116.

Syahrul, R. (2017) Buku Ajar Metodologi Peneletian Pembelajaran Bahasa Indonesia. SUKABINA Press.

Turmudi, M. (2017) 'Produksi Dalam Perspektif Ekonomi Islam', Islamadina: Jurnal Pemikiran Islam, 18(1), pp. 37-56.

Utami, P. (2020) 'Prinsip Produksi Bolu pada Usaha Mikro Kecil Menengah (UMKM) Dwi Putra Palembang Perspektif Ekonomi Islam', ADL ISLAMIC ECONOMIC: Jurnal Kajian Ekonomi Islam, 1(1), pp. 29-46.

Wulandari, R. S. and Widiyanti, A. (2017) 'Perancangan Pengukuran Efisiensi Kinerja Program Pendampingan Desa Di Kabupaten Sidoarjo Dengan Metode Dea', Seminar Nasional Sains dan Teknologi Terapan V, 1, pp. 69-74.

Yakub Pirdaus, R. (2019) 'Pengaruh Kondisi Sosial Ekonomi Keluarga Terhadap Motivasi Belajar Dan Implikasinya Terhadap Prestasi Belajar Siswa (Survey Pada Siswa Kelas Xi Ips Sma Negeri Se-Kabupaten Ciamis)'. Universitas Siliwangi.

Yusuf, M. and Agustang, A. (2020) 'Dinamika Perubahan Sosial Ekonomi Pada Masyarakat Kindang Kabupaten Bulukumba', Jurnal Sosialisasi: Jurnal Hasil Pemikiran, Penelitian dan Pengembangan Keilmuan Sosiologi Pendidikan, (2), pp. 31-37.

Zamzam, H Fakhry \& Aravik, H. (2020) Etika Bisnis Islam Seni Berbisnis Keberkahan. Yogyakarta: CV Budi Utama. 